\title{
Prevalence and hemato-biochemical studies in parasitic and non parasitic dermatological disorders in Surti buffalo and buffalo calves
}

\author{
H P Vishe*, K Pawar ${ }^{1}$, H K Gupta and G S Rao \\ Department of Veterinary Pathology, College of Veterinary Science and Animal Husbandry, \\ Navasari Agricultural University, Navsari, Gujarat, India. \\ 1. Animal Biochemistry Division, National Dairy Research Institute, Karnal, Haryana, India. \\ * Corresponding author email: vet25.hira@gmail.com \\ Received: 06-09-2011, Accepted: 11-10-2011, Published Online: 09-01-2012 \\ doi: 10.5455/vetworld.2012.230-235
}

\begin{abstract}
Present study investigated the prevalence and hemato-biochemical changes observed in the mange infested Surti buffaloes and buffalo calves. For prevalence study a total of 401 animals were screened for the infection for a period of one year. Systematic and detailed appraisal of haemato-biochemical profiles as well as skin scrapping specimens were carried out in seventy five cases. Hematological analyses of blood samples were done to evaluate changes in Hb, PCV, TEC, TLC and DLC counts. Biochemical analyses of serum samples were done to determine the concentrations of total protein, albumin, globulin, A:G ratio and serum zinc levels by Atomic Absorption Spectrophotometer (AAS). Infestation was found to be high in winter season. Infestation caused anaemia, increased TLC with eosinophilia. There was decrease in total protein as well as zinc concentration in serum in infested buffaloes.
\end{abstract}

Key words: Dermatology, Parasite, Disorder, Haematological changes, Biochemical changes.

To cite this article : Vishe HP, Pawar K, Gupta HK, Rao GS (2012) Prevalence and hemato-biochemical studies in parasitic and non parasitic dermatological disorders in Surti buffalo and buffalo calves, Vet. World. 5(4):230235, doi: 10.5455/vetworld.2012.230-235.

\section{Introduction}

Mange is a specific contagious skin disease, characterised by pruritic dermatitis and alopecia caused by a variety of ectoparasitic mites burrowing in or living on the skin. Seasonal incidence and effect of temperature on mange mites have been studied by several workers in India and abroad. Basu et al. (1952) found mange infestation as seasonal restricted to a few months in year such as October to March and infestation of mange in livestock was high during cold weather. There was a report of incidence of sarcoptic mange in buffaloes at Hissar in which out of 235 buffaloes of various ages examined 67 were infested with Sarcoptic scabii and infestation was reported highest in December (70 \%) (Tikaram and Ruprah, 1986). Parasitic infection and infestation, causes variations and changes in the blood picture as well as serum composition. Mange infested calves have been reported to develop moderate to severe degree of anaemia characterized by decrease in total erythrocyte count, packed cell volume and haemoglobin concentration in mange infested goats (Parija et al., 1995, Stromberg and Guillot, 1989, Dimri et al., 2007; Hafeez et al., 2007).
There was significant decrease in haemoglobin and increased in total leukocyte count during the caprine sarcoptic mange infestations in Black Bengal goats (Sengupta et al., 2008). Bala and Rath, 2006 reported increased total leukocyte count in mange affected calves.

Mixed chronic psoroptic and sarcoptic mange infestation in buffaloes caused poor growth rate, lymphopenia and decrease in albumin globulin ratio (A:G Ratio) (Randhawa et al., 1997). Buffaloes with clinical sarcoptic mange had significantly lower total protein and higher free fatty acids (FFA) and betahydroxybutyrate (b-HOB) in serum compared to apparently healthy controls (Dimri et al., 2007). There was also report of decreased serum zinc level in mange infested calves (Bal and Rath, 2006).

The present study was undertaken to understand the prevalence of mange in the Surti buffalo and buffalo calves and also to investigate the haematobiochemical changes caused by the infection.

\section{Materials and methods}

Incidence of mange: A total of 401 animals were screened from June 2009 to June 2010 with an average 

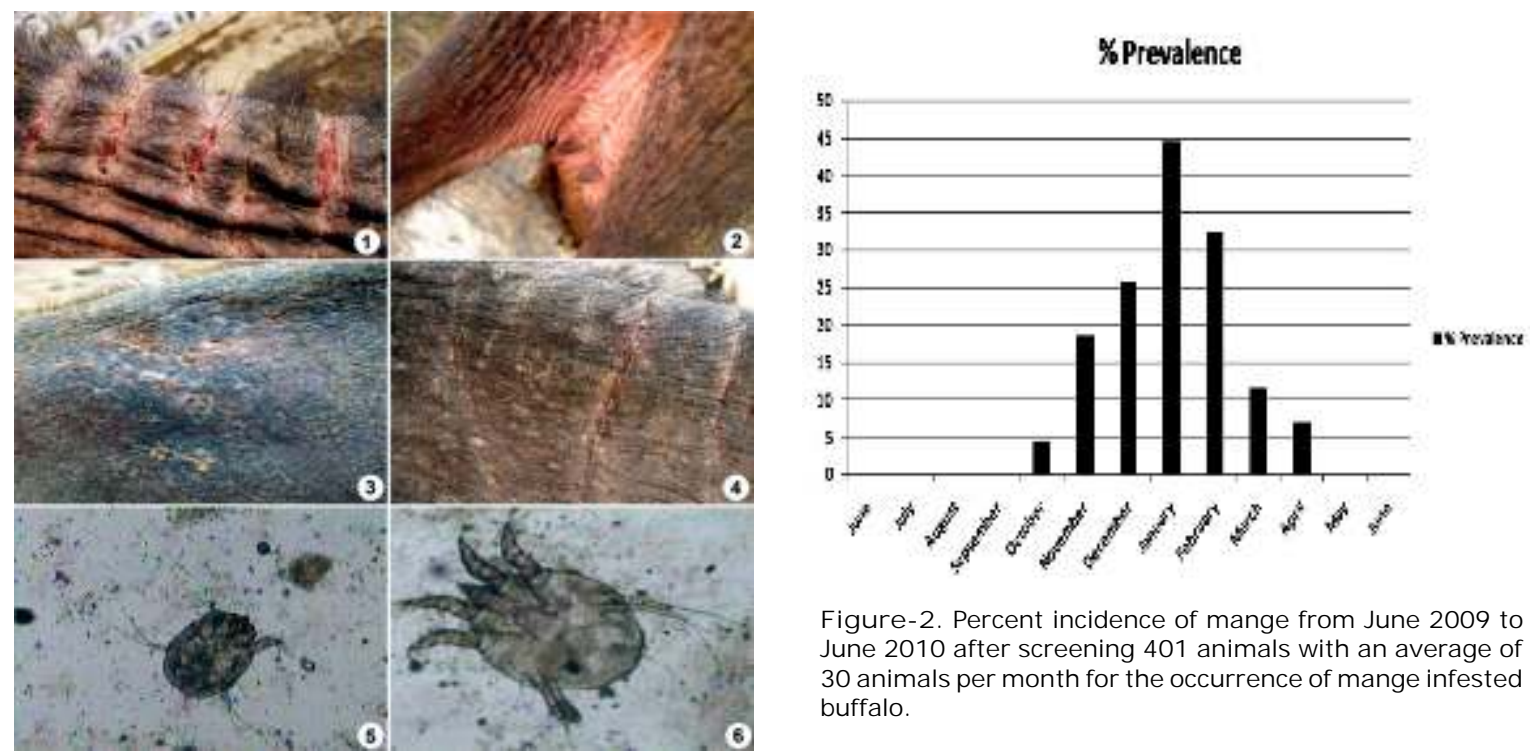

Figure-2. Percent incidence of mange from J une 2009 to J une 2010 after screening 401 animals with an average of 30 animals per month for the occurrence of mange infested buffalo.

Figure-1. Gross and microscopic findings of mange in surti buffaloes and buffalo calves. (1) Ulcerative, haemorrhagic lesions on flank in buffalo calf. (2) Thickened and folded skin at flank region with scaly hairs and ulceration in calf. (3) Scab formation on buffalo skin. (4) Eczematous lesions. (5) Microscopic appearance of Sarcoptic scabie. (6) Microscopic appearance of Psoroptic bovis.

of 30 animals per month for the occurrence of mange infested buffalo from dairy farms located in and around Navasari and Livestock Research Station, NAV, Navasari. Clinical signs/ symptoms and microscopic identification of type of mange were followed in the study.

Age, sex and breed wise prevalence of mange: The animals were grouped age (young/adult), sex and breed (Surati/non-descript) wise to study the prevalence of mange in the animal. For age wise grouping, animals above 1 year were considered as an adult whereas below that were considered as young.

Grouping of animals for hemato-biochemical studies: For hematobiochemical studies a total of 75 animals randomly selected were grouped into healthy (group A), parasitic (group B) and non-parasitic (group C). (Group A: Healthy animals not suffering from any disease, Group B: Animals infested with dermal parasites showing lesions, Group C: Animals showing dermatological lesions but not infested with dermal parasites).

Blood sample collection and processing: The blood was collected from Surti buffalo calves and buffaloes from dairy farms located in and around Navsari and Livestock Research Station, N.A.U. Navsari. The blood samples were collected from jugular vein into commercial Blood Vacutainers coated with Ethylene Diamine Tetra Acetic Acid (EDTA).

Biochemical analyses were carried out in the
Animal Disease Investigation Office Navsari, while the estimation of zinc was carried out in the Department of Agricultural Chemistry and Soil Science, Navsari Agricultural University, Navsari.

Separation of serum and preservation: Sera samples were also collected from these animals and stored at $-20^{\circ} \mathrm{C}$ after addition of $0.1 \%$ Merthiolate as preservative for further analysis.

Estimation of blood parameter: Packed cell volume (PCV) was performed as per the method given by Jain (1986) and the values were expressed in percentile. PCV and $\mathrm{Hb}$ were estimated by the method described by Jain (1986). Blood smear were prepared from fresh blood.

Estimation of serum biochemical parameter: Biochemical assay of serum samples was carried out for serum total protein, albumin by using Ecoline diagnostic kits supplied (Merck Specialities Pvt. Ltd., Ambernath-421501) by auto serum analyzer (Selectra Junior, Merck Pvt. Ltd.)

Calculation of serum Albumin:Globlin (A:G) ratio: Albumin globulin ratio $(\mathrm{A}: \mathrm{G})$ was calculated by dividing concentration of albumin in $\mathrm{g} / \mathrm{dl}$ and concentration of globulin in $\mathrm{g} / \mathrm{dl}$.

Estimation of Zinc: Concentration of zinc ( $\mathrm{Zn}$ ) was estimated using Atomic Absorption Spectrophotometer (ECIL Model, AAS 4141) as per the method described earlier (Hackely et al., 1968). 
Table-1: Haemato-biochemical parameters of different groups during the study period.

\begin{tabular}{llll}
\hline Parameters & Group A & Group B & Group C \\
\hline $\mathrm{Hb}(\mathrm{g} / \mathrm{dl})$ & $12.06 \pm 0.46^{\mathrm{a}}$ & $8.06 \pm 0.17^{\mathrm{b}}$ & $9.65 \pm 0.37^{\mathrm{c}}$ \\
$\mathrm{PCV}(\%)$ & $40.2 \pm 1.35^{\mathrm{a}}$ & $26.53 \pm 0.49^{\mathrm{b}}$ & $31.5 \pm 0.93^{\mathrm{c}}$ \\
$\mathrm{TEC}\left(10^{6} /\right.$ cumm) & $7.32 \pm 0.36^{\mathrm{a}}$ & $5.40 \pm 0.23^{\mathrm{b}}$ & $6.09 \pm 0.25^{\mathrm{ab}}$ \\
$\mathrm{TLC}\left(10^{3} /\right.$ cumm) & $9.78 \pm 0.23^{\mathrm{a}}$ & $12.02 \pm 0.35^{\mathrm{b}}$ & $10.15 \pm 0.38^{\mathrm{a}}$ \\
Lymphocytes & $69.8 \pm 0.86^{\mathrm{a}}$ & $75.01 \pm 0.53^{\mathrm{b}}$ & $70.72 \pm 0.77^{\mathrm{a}}$ \\
Monocytes & $3.4 \pm 0.40^{\mathrm{a}}$ & $2.07 \pm 0.13^{\mathrm{b}}$ & $2.11 \pm 0.19^{\mathrm{b}}$ \\
Neutrophils & $23.00 \pm 0.94^{\mathrm{a}}$ & $12.55 \pm 0.46^{\mathrm{b}}$ & $20.33 \pm 0.56^{\mathrm{a}}$ \\
Eosinophils & $3.00 \pm 0.70^{\mathrm{a}}$ & $9.92 \pm 0.70^{\mathrm{b}}$ & $6.38 \pm 0.45^{\mathrm{c}}$ \\
Basophils & $0.80 \pm 0.20^{\mathrm{a}}$ & $0.42 \pm .079^{\mathrm{a}}$ & $0.44 \pm 0.12^{\mathrm{a}}$ \\
Total Protein $(\mathrm{g} / \mathrm{dl})$ & $8.06 \pm 0.20^{\mathrm{a}}$ & $6.72 \pm 0.12^{\mathrm{b}}$ & $5.93 \pm 0.17^{\mathrm{c}}$ \\
Albumin(g/d) & $3.14 \pm 0.15^{\mathrm{ab}}$ & $4.20 \pm 0.18^{\mathrm{b}}$ & $3.03 \pm 0.30^{\mathrm{a}}$ \\
Globulin(g/dl) & $4.88 \pm 0.29^{\mathrm{a}}$ & $2.51 \pm 0.15^{\mathrm{b}}$ & $2.97 \pm 0.24^{\mathrm{b}}$ \\
Albumin Globlin Ratio $(\mathrm{A}: \mathrm{G})$ & $0.65 \pm 0.06^{\mathrm{a}}$ & $2.22 \pm 0.25^{\mathrm{b}}$ & $1.3 \pm 0.24^{\mathrm{a}}$ \\
Zinc $(\mu \mathrm{mol} / \mathrm{L})$ & $15.58 \pm 0.55^{\mathrm{a}}$ & $7.30 \pm 0.23^{\mathrm{b}}$ & $10.51 \pm 0.64^{\mathrm{c}}$ \\
\hline
\end{tabular}

Different Parameters for three different groups: healthy (group A), parasitic (group B) and non-parasitic (group C). Data is represented in \% (percent) \pm standard error mean (SEM) from three different slides of each sample. Values with different superscript letters $(a, b, c, a b)$ between columns differ significantly $(P<0.05)$.

Statistical analysis: The data generated on haematological, biochemical and trace minerals were subjected to statistical analysis for test of significance by applying appropriate statistical methods (Snedecor and cocheran, 1994).

\section{Results}

The classical clinical signs of mange including ulceration and hemorrhages at the inguinal region, folded skin at neck regions, eczematous and scab formation were observed on the body of animal along with presence of sarcoptic and psoroptic species (Fig. 1). Month wise prevalence studied for sarcoptic mange revealed an increasing trend from October to April. Mange was not observed between May to September (Fig. 2). Winter season was found to be more conductive for the spread of the disease $(29.67 \%$ ) followed by summer $(5.05 \%)$ and autumn $(0 \%)$.

Age, sex and breed wise prevalence of mange: The age wise prevalence of dermatological disorders was found to be $73.07 \%$ and $26.92 \%$ in young and adults, respectively. The sex wise prevalence of dermatological disorders was found to be $63.46 \%$ and $36.53 \%$ in male and female respectively. For Surti breed of buffaloes the prevalence of dermatological disorders was found to be $75 \%$ as compared to nondescript breed which was $25 \%$.

Estimation of blood parameters: Haematocrit values were lower for group B and group C whereas that of group A had normal values. Same result was also observed for haemoglobin and erythrocyte count. The significant increase was observed for TLC of group B as compared to group A and group C. There was marked increase and decrease values for eosinophils and neutrophils respectively in group B as compared to healthy animal group. The result of PCV, $\mathrm{Hb}, \mathrm{TEC}$ and TLC and DLC has been presented in the Table-1.

Estimation of serum biochemical parameters: Total protein value for group C followed by group B were significantly lower than healthy animals. There was no change in albumin values for group $\mathrm{B}$ and $\mathrm{C}$ as compared with group $\mathrm{A}$, but for globulin there was decrease for group B and C as compared with group $\mathrm{A}$. The value for albumin:globulin ratio was significantly high for group B as compared to healthy animals. Serum zinc concentration was highly decreased for group B as compared to group A followed by group C. The result of total protein, albumin, globulin, albumin: globulin ratio and concentration of zinc according to group has been represented in the Table-1.

\section{Discussion}

In case of mange infestation host reactions were associated with response to mites and their fecal deposits which usually occurred three weeks after the initial infestation and subsequently the reaction time becoming much shorter after repeated exposures. Initial lesions could occur anywhere on the body, often localized where the hair tends to be thin and prone to scratches/ injuries of epidermis such as head from 
there the infestation can spread quickly causing generalized mange. Infestations generally appeared as papular eruptions with erythema, pruritis, and hair loss. With the progress of lesions affected areas become thickened, with crusts or exudates and consequently infected by secondary microbial invaders after excoriation of the skin due to scratching and rubbing (Gary and Durden, 2009).

Based on the screening of skin scrapping samples, overall prevalence of sarcoptic mange appeared to be $69.33 \%$ in buffalo and buffaloes calves. Similar prevalence rates ranging from $23.60 \%$ to $94 \%$ have been reported in buffalo calves (Tikaram and Ruprah, 1986) and $89.5 \%$ in Zymbia (Munang'andu et al., 2010). There was higher prevalence of mange infection in male calves as compared to females (Nooruddin et al., 1986). Young animals were more prone to infestation as compared to adult animals (Naresh et al., 2005; Hafeez et al., 2007). In present study it appeared that winter season was found to be more conductive for the spread of the mange (29.67\%). The month wise prevalence of sarcoptic mange revealed an increasing trend from October to April substantiating earlier reports (Patel et al., 2003). Higher incidence during cold period was attributed to low ambient temperature (aT), which favoured the propagation of mites. Cold climate ranging between $21-27^{\circ} \mathrm{C}$ have been reported to favour the propagations of mites (Tikaram and Ruprah, 1986).

In the present study $\mathrm{Hb}$ count, $\mathrm{PCV}$ count and TEC level in the both groups $\mathrm{B}$ and $\mathrm{C}$ were lower as compared to healthy animals, which could be to significantly lowered erythrocyte indices, hematocrit and increased erythrocyte fragility (Jain, 1986) or due to toxemia caused by mites (Pas'Ko and Chotchaev, 1974). Mean Packed cell volume (PCV) and Hemoglobin $(\mathrm{Hb})$ concentration were significantly lower in mange affected group due to the decreased erythroid elements in blood (Tung et al., 1975). Significant reduction of lower hematological values in buffaloes and buffalo calves affected with sarcoptic mange has also been reported by earlier workers (Parija et al., 1995; Patel et al., 2003; Dimri et al., 2007). Total erythrocyte counts appeared significantly reduced in mange supporting the earlier reports that sarcoptes mites affect erythropoiesis leading to marked reduction in total erythrocyte count (Hogg, 1979). The TLC level in mange infested animal was found to be elevated in the present study. Similar type of increased total leukocyte count was reported by earlier studies (Bala and Rath, 2006; Bal et al., 2009).

In case of blood smear examination there was eosinophilia in mange infested animals, which could be associated with ongoing allergic reactions to mites or their products (Jain, 1986; Yousaf et al., 1989). Eosinophilia has been linked to antigen antibody interactions in tissues rich in mast cells, such as skin, as well as to protracted host parasite reaction (Duncan and Prasse, 1979; Ramprabhu, 2001).

In contrast to parasitic group, total protein concentration appeared significantly lesser in nonparasitic group. Protein deficiency indicated malnutrition, disturbed regressive hepatic functional status (Raval, 1997) and glomerular filtration capacity (Barron, 1982). Group C was found to be significantly hypoproteinemic while group $\mathrm{B}$ animals marginally protein deficient, supporting earlier reports (Anon, 1982; Kumar and Sharma, 1993; Kaneko et al., 1999; Sethi, 2001; Dimri et al., 2007). In parasitic group total protein concentration appeared significantly lower (Bala and Rath, 2006; Dimeri et al., 2007). These findings suggested poor nutritional status. Sarcoptic mange in buffaloes was often associated with severe pruritis, which led in to anorexia (Radostatis et al., 2001). The lowered level of serum protein could also be due to loss of plasma proteins in dermatitis. Decreased concentration of serum globulins was also reported earlier (Kamboj, 1991; Dadhich and Khanna, 2008).

Of all the essential trace minerals, zinc is referred as the most vital and skin disorders associated with dietary zinc deficiency ranged from hyperkeratosis (Radostatis et al., 2001) to infertility (Patel, 2003) and immunodeficiency (Prasad, 1966; Nockels and Blair, 1996 Tizzard, 1998). Zinc (Zn) is known to play an important role in the immune system, the protective shield of the skin to gene regulation within lymphocytes, as well as normal development and functioning of cells mediating nonspecific immunity and stabilization of cell membranes of macrophages (Shankar and Prasad, 1998). Severe Zn deficiency, reported to adversely affect immune status, characterized by susceptibility to opportunistic infections as in dermatitis, enteritis and alopecia (Walsh et al., 1994; Zalewski, 1996). In the present study serum zinc level was lowest in group $\mathrm{B}$ then group $\mathrm{C}$ as compared with group $\mathrm{A}$. Zinc absorption was reported to be antagonised by Cadmium $(\mathrm{Cd})$ and deficiency could be a consequence of chronic $\mathrm{Cd}$ toxicity. (Gaw et al., 2008).

The present investigation clearly brought out that Sarcoptes scabii was the most common etiological factor of mange in buffaloes, while Psoroptic bovis appeared to be next important cause of parasitic mange. As far as the non-parasitic dermatoses were concerned hypoproteinemia and dietary zinc deficiency 
appeared to be the major causes which could be construed either to malnutrition and deficiency of zinc or its disturbed absorption, probably associated with interference by cadmium accumulation in fodder. The present study has established comparative influence of mites as well as deficiency of proteins and essential trace mineral zinc in perpetration of dermatological syndromes among Surti buffaloes and their followers. The syndromes deleterious effects of cadmium contamination warrant detailed scrutiny since, Ankleshwar or Vapi industrial corridor has been deemed as the most polluted zone of not only South Gujarat but the entire state.

\section{Acknow ledgments}

The authors are grateful to Navsari Agricultural University, Navsari, Gujarat and Dr. N.H.Kelawala, Dean, Veterinary College, for providing us with the necessary facilities as well as financial help to carry out this study work. We also thank Wamja Hitesh for his help in sample collection.

\section{Conflict of interest} interest.

Authors declare that they have no conflict of

\section{References}

1. Anon. (1982). Animal Disease Diagnostic Laboratory and Disease Surveillance Unit, National Dairy Development Board, Anand.

2. Bal, M.S., Mahajan, V., Ashuma, Paramjit Kaur, Sharma, S., Renu, Rath, S.S. (2009). Efficacy of abamectin against sarcoptic mange in adult buffaloes. Indian Vet. J., 86:674-675.

3. Bala, A., Rath, S.S. (2006). Studies on haematobiochemical alterations due to Sarcoptic mange in buffalo calves. Indian Vet. J. 83:230-231.

4. Barron, D.N. (1982). A short text book of Chemical Pathology. In: The English language book society $4^{\text {th }}$ 222 Edn. Hodder and Stoughton. 106-107.

5. Basu, B.C., Menon, P.B., Sengupta, C.M. (1952). Seasonal incidence and effect of temperature on mange mites. Indian Vet. J. 22:143-149.

6. Dadhich, H., Khanna, R. (2008). Pathological, haemato-biochemical and immunological studies of cutaneous ectoparasitoses in dogs. Proceedings, The $15^{\text {th }}$ Congress of FAVA -OIE Joint Symposium on Emerging Diseases.

7. Dimri, U., Ranjan, R., Singh, S.K., Shrma, M.C., Swarup, D., Dwivedi, P., Shrma, A.K.,Katariya, M. (2007). Clinico-pathological and haematobiochemical changes in buffaloes with sarcoptic mange. Indian Journal of Veterinary Pathology. 31:160-162.

8. Duncan, J.R., Prasse, K.W. (1979). Veterinary
Laboratory Medicine, Ames, Iowa. Iowa State University-Press, 42-43.

9. Gary, R.M., Durden. (2009). Medical and Veterinary Entomology $2^{\text {nd }} 233$ Edn. Elsevier Publication, Amsterdam. 469-470.

10. Gaw, A., Murphy, M.J., Cowan, R.A., O'Reclly, D.J Stewart, M.J., Shephard, J. (2008). Clinical Biocheistry, $4^{\text {th }}$ Edn., Churchill Livingstone, Elsevier Edinburg, Philadelphia, 114-115.

11. Hackely, B.M., Smith, J.C., Halsted, J.A. (1968). A simplified method for plasma zinc determination by atomic absorption spectrophotometry. Clinical Chemistry. 14(1).

12. Hafeez, U.A., Sindhu, Z., Iqbal, Z., Jabbar, A., Tasawar, Z. (2007). Prevalence of Sheep Mange in District Dera Ghazi Khan (Pakistan) and Associated Hematological/ Biochemical Disturbances. International J. of Agri. \& Biology. 6:917-920.

13. Hogg, A. (1979). Mange problems are sobbing feed efficiency. Hog Farm Mange. Australian Vet. J., 16:29-30.

14. Jain, N.C. (1986). Schalm's Veterinary Hematology, $4^{\text {th }}$ Edn. Lea \& Febiger Philadelphia, 36-64.

15. Kamboj, D.S. (1991). Clinical studies on bacterial and parasitic dermatitis with special reference to diagnosis and treatment. M. V. Sc. thesis, Punjab Agric. Univ., Ludhiana.

16. Kaneko, J.J., Harvey, J.W., Bruss, M.L. (1999). Clinical Biochemistry of Domestic Animals. $5^{\text {th }}$ Edn. Harcourt Bruce and Co. Asia PTE Ltd., Singapore. 619:680.

17. Kumar, S., Sharma, M.C. (1993). Haematobiochemical changes during fertile and non fertile estruses in rural buffaloes. Buffalo J.,6:69-73.

18. Munang'andu, H.M., Siamudaala, V.M., Matandiko, W., Munyeme, M., Chembensofu, M., Mwase, E (2010). Mite epidemiology and treatment in African buffalo (Syncerus caffer) calves captured for translocation from the Kafue game management area to game ranches. BMC Veterinary Research, 6:29.

19. Naresh, R., Swarup, D., Sharma, M.C., Ranjan, R. (2005). Clinical management of sarcoptic mange in Indian buffalo calves with a botanical ointment. Veterinary Record, 156:684-685.

20. Nockels, C.F., Blair, R. (1996). Antioxidents improve cattle immunity following stress. Animal Feed Science and Technology, 62:59-68.

21. Nooruddin, M., Gill, B.S., Singh, J., Singh, K. (1986). Buffalo J. 2:81. Parija, B.G., Misra, S.C., Sahoo, P.K., Rao, A.T., Bisoi, P.C. (1995). Clinical pathology of sarcoptic mange in black Bengal Goats. Indian Vet. J., 72:572-576.

22. Pas'Ko, G.G., Chotchaev, A.D. (1974). Clinical and morphological features of sarcoptic mange in goats. Veterinariya Moscow, 12:58-9.

23. Patel, J.S., Patel, P.R., Panchasara, H.H., Brahmaxatri, K.G. (2003). Epizootiology of sarcoptic mange in buffalo calves. Indian Vet. J. 80:972-974. 
24. Patel, P.A. (2003). Studies on repeat breeding in Mehsani buffaloes with special reference to microbial and biochemical status .M. V. Sc. Thesis, submitted to GAU, S. K. Nagar.

25. Prasad, A.S. (1966). "Zinc Metabolism" Thomas, Springfield, Illinois.

26. Radostatis, O.M., Blood, D.C., Henderson, J.A. (2001).Veterinary Medicine. $9^{\text {th }}$ Edn. ELBS Baillire, Tindall, London.

27. Ramprabhu, R.A., Subramanian, M., Nambi, A.P., Prathaban, S., Dhanapalan, P. (2001). Concurrent sarcoptic and psoroptic mange infestation in Bubalus bubalis. Vet. Arhiv., 71:53-56.

28. Randhawa, C.S., Brar, R.S., Sharma, D.R., Randhawa, S.S. (1997). Biochemical responses in mixed chronic Psoroptic and Sarcoptic mange of buffaloes. Tropical Animal Health and Production, 29:253-254.

29. Raval, S.K. (1997). Epidemiological surveillance, clinico-pathology,diagnostic and techno economic aspects of Fasciolasis in buffaloes. Ph.D. Thesis submitted to Gujarat Agricultural University.

30. Sengupta, P.P., Pal A.K., Basu, A., Basak, D.K. (2008). Histopathological and Histochemical changes in the skin of Black Bengal goats with induced Sarcoptic mange infection. Indian Vet. J.,85:480-482.

31. Sethi, S. (2001). Serum biochemical profile and corresponding pathomorpholgic observations on parathyroid in Mehsani buffaloes. A M.V.Sc. Thesis submitted to GAU.

32. Shankar, A.H., Prasad, A.S. (1998). Zinc and immune function: the biological basis of altered resistance to infection 1-3.Am. J. Clin. Nutr., 68:447S-63S.

33. Snedecor, G. W. and W. G. Cochran. (1994). Statistical Methods. $6^{\text {th }}$ Edn. In: Oxford and IBH Publishing Company, Calcutta.

34. Stromberg, Guillot. (1989). Pathogenesis of psoroptic scabies in Hereford heifer calves. Am.J. Vet. Res., 50:594-601.

35. Tikaram, S.M., Ruprah, N.S. (1986). Incidence of sarcoptic mange in buffaloes in India. Tropical Animal Health and Production, 18:86-90.

36. Tizzard, I.R., 1998. Veterinary Immunology. $5^{\text {th }}$ Edn. W. B. Saunders Company Publishers. 465-469.

37. Tung, H.T., Cook, F.W., Wyatt, R.D. (1975). Anaemia caused by ectoparasitic infestation. Poultry Sci., 54:1962-1969.

38. Walsh, C.T., Sandstead, H.H., Prasad, A.S., Newberne, P.M., Fraker, P.J. (1994). Zinc health effects and research priorities for the 1990's. Environ Health Perspect. 102:5-46.

39. Yousaf, Y.A., Alkhalidi, N.W., Zend, M.M. (1989). A treatment of scabies with ivermectin. Indian J. Vet. Med., 9:22-3.

40. Zalewski, P.D. (1996). Zinc and immunity: implications for growth, survival and function of lymphoide cells. J. Nutr. Immunol. 4:39-80. 